\title{
DOCUMENTÁRIOS COM GINGA, PERSPECTIVAS DO DOCUMENTARISMO: DOS WEBDOCS À TV DIGITAL INTERATIVA BRASILEIRA
}

\author{
Bráulio de Britto Neves*
}

\begin{abstract}
Resumo: Com a ampliação do potencial dialógico da nova TV digital interativa brasileira, a articulação de práticas de produção colaborativa de cibertextos transmedia com ampla participação dos públicos e difusão distribuída abre horizontes para a inovação em práticas documentárias. $\mathrm{O}$ desafio para o desenvolvimento da potencialidade comunicativa e poética da TV digital interativa deve ser compreendido como a demanda de desenvolvimento de uma estilística nova, congruente com novos parâmetros éticos das relações realizadas através das imagens documentárias.
\end{abstract}

Palavras-chave: TVdi, i-docs, cibertexto, transmídia, colaboração, participação.

Resumen: Con la expansión del potencial dialógico de la nueva televisión digital interactiva brasileña, la articulación de las prácticas de producción colaborativa de cibertextos transmedia con amplia participación de público y difusión distribuida abre horizontes a la innovación en las prácticas documentales. El reto para el desarrollo del potencial comunicativo y poética de la televisión digital interactiva debe ser entendido como la demanda de desarrollo de una estilística nueva, congruente con los nuevos parámetros éticos de las relaciones realizadas a través de imágenes documentales.

Palabras clave: iDTV, i-docs, cibertexto, transmedia, colaboración, participación.

Abstract: With the ampliation of the dialogic potential of the new brasilien interactive digital television, the articulation of collaborative production practices of transmedia cibertexts with a wide participation of the public and a distributed difusion, horizonts are opened for the inovation in documentary practices. The challenge for the development of communicative and poetic potential of interactive digital TV should be understood as the demand for developing a new stylistic, congruent with new ethical parameters of relations performed through documentary images.

Keywords: IDTV, i-docs, cybertext, transmedia, collaboration, participation.

Résumé: Avec l'expansion du potentiel dialogique de la nouvelle télévision numérique interactive au Brésil, l'articulation des pratiques de production de collaboration cybertexts transmédia avec une large participation du public et leur diffusion, ouvre des horizons pour l'innovation dans les pratiques documentaires. Le défi pour le développement du potentiel communicatif et poétique de la télévision numérique interactive devrait être

* Pontifícia Universidade Católica de Minas Gerais, Departamento de Comunicação e Artes, Grupo de Pesquisa Poéticas audiovisuais: Dispositivo e Temporalidade. CEP 31235 040, Belo Horizonte-MG, Brasil. E-mail: brauliobrittoneves@yahoo.com.br

Pesquisa financiada pelo Programa Nacional de Pós-Doutorado, CAPES, Brasil.

Submissão do artigo: 01 de julho de 2015. Notificação de aceitação: 21 de agosto de 2015. 
compris comme la demande de développement d'un nouveau style, en harmonie avec les nouveaux paramètres éthiques des relations réalisées à travers des images documentaires. Mots-clés: iDTV, i-docs, cybertexte, transmedia, la collaboration, la participation.

Hoje, além de 15 milhões de set-top boxes Ginga, distribuídos para famílias inscritas no bolsa-família, em 2015, já foram vendidos mais de 42 milhões de receptores de TV digital com o sistema - sem contar os aparelhos smartphones capazes de receber o sinal (Novaes e Diniz, 2015).

No entanto, é ainda incipiente o esforço, da parte dos teledifusores e produtores audiovisuais comerciais em explorar os novos recursos interativos. Esta inércia é atribuída, por alguns, à falta de modelos de produção e de negócios para a geração de conteúdo interativo; por outros, ao temor de que um conjunto de novas relações de produção e apreciação de televisão coloquem em risco os modelos de negócios das empresas já estabelecidas - que, como se depreende dos repetidos "socorros" financeiros concedidos pelo Estado nos últimos anos, não ostentam grande segurança quanto à sua lucratividade futura (Tozzeto, 2012; Soares, 2013; Motta, 2009; Dantas, 2009).

Argumentamos, primeiramente, que a introdução da interatividade no audiovisual - na televisão digital e no vídeo on-line - é potencialmente indutora de um novo ciclo de experimentação de novos arranjos participativos e colaborativos. Do ponto de vista normativo, na perspectiva de um processo aberto de democratização da sociedade (Dryzek, 2000) deve-se considerar como medida de sucesso dos novos arranjos de produção a intensidade e a extensão segundo as quais eles efetivam potenciais democráticos, pluralistas e dialógicos, da televisão (Matuck, 1995). No caso do audiovisual não-ficcional, isso se traduziria na emancipação dos três públicos que a comunicação audiovisual documentária coloca em relação: 
os telespectadores (a se transformarem em teleusuários ${ }^{1}$ ); atores sociais (que passam de "informantes nativos" a voluntários); e dos produtores de audiovisual (que se assumem como propositores, ${ }^{2}$ despindo-se de pretensões demiúrgicas).

Segundo, nas circunstâncias atuais de fragmentação patológica da esfera de visibilidade pública política, essa tripla emancipação ganha positividade, em termos ético-comunicativos, ${ }^{3}$ apenas na medida em que se refere à ampliação da capacidade de instaurar espaços de interação de reflexividade discursiva de caráter universalista. Nessa direção, pretendemos mostrar que o uso democrático da interatividade na comunicação audiovisual necessita se desenvolver como uma interpretação da convergência de mídias, que ultrapasse seu entendimento como ardil de apropriação "semanticorporativa" da produtividade dos públicos apreciadores (Jenkins, 2003), na perspectiva crítica de uma produção transmidiática, que supere a antinomia entre informação e narrativa, proposta pela crítica benjaminiana (Benjamin, 2003: “O Narrador...”).

$\mathrm{Na}$ primeira seção, vamos fazer um breve percurso pela produção audiovisual de função referencial - noticiários e documentários observando a crescente tendência à horizontalização das relações entre apreciadores, produtores e atores sociais. Nas quatro subseções, serão caracterizados quatro principais tropos retóricos, que se sucederam historicamente como metáforas da comunicação cinematográfica. Em

\footnotetext{
${ }^{1}$ Segundo Cirne et al. (2009: 102): “... os recursos complementares convertidos em dispositivos interativos, somados à postura pró-ativa dos teleusuários (que agora não são mais telespectadores, mas também usuários), podem suprir uma natureza às vezes superficial de algumas matérias telejornalísticas que têm sua veiculação em função do fator tempo." A observação sobre a diferença entre públicos usuários e consumidores, ref. Benkler (2000).

${ }^{2}$ A nossa principal referência para a concepção de "propositores" provém do trabalho e dos textos de Lygia Clark, artista plástica neoconcretista brasileira, que se tornou famosa por empreender um sistemático esforço de desmaterialização do objeto artístico, explorando poeticamente a base sensorial da percepção corporal e ambiental.

${ }^{3}$ Isto é, referidos à ética da comunicação, tal como elaborada na teoria da Ação Comunicativa, dde Habermas e Apel.
} 
"Sondando a nova ético-estilística: Interatividade, "investigativismo" e colaboração", nossa tarefa será observar quais seriam as mudanças de pressupostos ético-politicos do documentário conforme as diferentes condições de implicitação do apreciador no texto vinculadas às circunstâncias da sua imersão propriamente cinematográfica. Referimo-nos especialmente das possibilidades emersas quando a textualidade audiovisual documentária se torna cibertextual e interativa. A próxima secção, "Ciber-o QUÊ?” é uma exploração livre das implicações ético-estilísticas, para o documentário, das variações de propriedades ergódicas do texto não linear (i. e. , definidoras da topologia textual - para Aarseth, 1994; 1997). A partir delas, avaliam-se também as diferentes condições de comunicação documentária, de acordo com graus dirferentes de interatividade. Na quarta seção, queremos mostrar como é que as complementaridades entre características da interatividade do webdocumentário e dos programas de TV digital, tornam a participação dos públicos algo muito além do mero chamariz, transformando-a no cerne ético-estilístico para novos formatos interativos.

Nas duas últimas seções, faremos um passeio sobre vertentes de investigação poéticas e poético-políticas. Na quinta, sustentamos que a procedimentalização da produção colaborativa propicia a construção de estruturas narrativas distribuídas, de produção colaborativa. Na sexta e última, esboçamos algumas reflexões sobre o sentido de universalidade a ser devolvido às comunicações públicas pelos arranjos audiovisuais interativos. Expressamos nosso juízo sobre o caráter promissor da associação, nos arranjos de enunciação audiovisual, de interatividade com produção colaborativa, como vetor de regeneração da reflexividade universalista do discurso público. 


\section{Tropos da deriva ético-estilística do audiovisual documentário}

Para compreender o contexto da emergência de práticas de produção colaborativa de multidão e sua vinculação à praxes políticas de instauração de espaços de visibilidade contrapública, é preciso reconstruir criticamente a história dos estilos e dos ethoi do cinema documentário. Desde meados dos anos 1960, experimentos artísticos e ativistas com produção audiovisual de função referencial, documentários, cine-reportagens e alguns experimentos de TV já vêm colocando em questão as pretenções "docentes" do jornalismo, das ciências sociais e do cinema documentário, pondo em dúvida a centralidade deles na produção do conhecimento que a sociedade necessita produzir sobre si mesma, para si mesma.

Para tentar dar conta dos dilemas da autorrepresentação cinematográfica da realidade social, as práticas de produção de imagens não ficcionais experimentaram uma deriva histórica na qual emergem vários conjuntos de expedientes discursivos, identificados como "modos documentários" (Nichols 1994) ou "campos éticos" (Ramos, 2005, 2008). Estes conjuntos e valores e protocolos de expressão emergem pela coalescência do desenvolvimentos de máquinas lógicas (Noth, 2002), principalmente as que torna compartilháveis os atos de percepção, (Sobchack, 1992; Neves, 2010 ), com a transformação de convenções de argumentação narrativa e praxes de difusão e de apreciação do audiovisual. Cada conjunto tem vantagens heurísticas e limitações epistemológicas específicas, que se manifestam nos seus procedimentos, estilemas e arranjos de produção típicos. Para que aglomerados retóricos permaneçam coesos, é doecisiva a articulação entre componentes intratextuais, paratextuais e cotextuais. Na produção do sentido de documentário de uma enunciação audiovisual, não basta que os componentes imagéticos do filme sejam indiciais e que os simbólicos sejam hipo-indiciais (p. ex., povoados de 
dêiticos e marcas da embreagem no universo de discurso "realidade histórica"). É preciso que, além de garantir que essas operações sejam reconhecidas enquanto marcas de uma função referencial, tenham sidos realizados procedimentos de indexação institucional (Carroll, 1996), inseridas uma série de marcas de correspondência entre "consígnias intra e extratextuais" (Odin, 1984) que confirmem a eficácia epistêmica do filme. Por isso, propomos identificar esses agregados de expedientes retóricos de conjuntos ético-estilísticos: eles jamais servem apenas a finalidades estéticas, mas também jamais apenas a propósitos político-comunicativos específicos. ${ }^{4}$

É relevante, para interpretar os desdobramentos políticos da sucessão de conjuntos retóricos na comunicação audiovisual documentária observar como representações políticas são enredadas não como argumentos ou narrativas simbólico-verbais, mas também nos atos de compartilhar percepções corporais. A imersão cinematográfica é capaz de sugerir ou induzir ethoi corporais no público, frequentemente desestabilizando corporalidades pré-existentes (David Thomas, 1995, 1996). O cinema permite a reconfiguração corporal de relações intersubjetivas. É desde esse nível pré-reflexivo, inconsciente e corporal, que, através da imersão em enunciações documentárias, é possível realizar experimentos com relações políticas.

No quadro abaixo, essa dimensão da deriva hístórica do documentário é correlacionado às transformações de substratos materiais, circuitos de difusão e condições de apreciação.

\footnotetext{
${ }^{4}$ A nosso juízo, um novo desses conjuntos emerge com o recorrente emprego do audiovisual para a criação de espaços de visibilidade e participação política "ativista", que chamamos de documentário político-prefigurativo (Neves, 2011).
} 


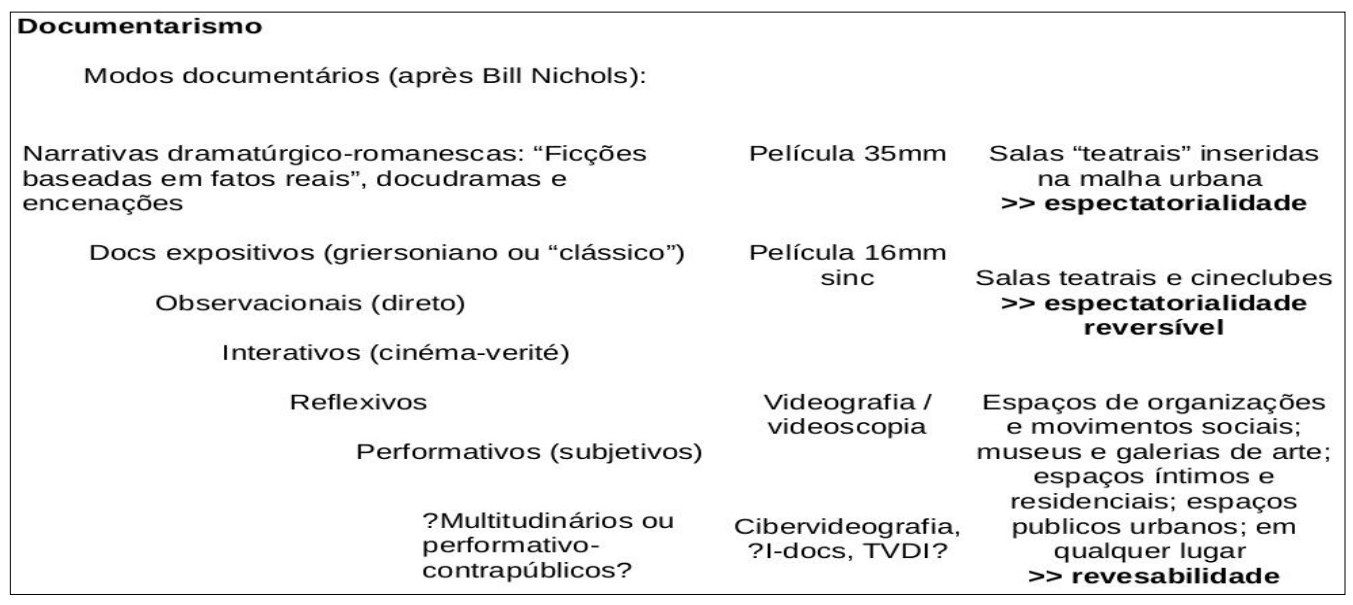

Tal como ocorre com estilos de época que se tornam gêneros literários, os conjuntos ético-estilísticos do documentário se sucederam historicamente, mas seus elementos típicos que eventualmente são reapropriados, em obras idiossincráticas, ou em blends ético-estilísticas comerciais. É instrutivo considerar, por exemplo, o caso do uso da encenação no documentário: hoje, ela é estigmatizada como se fosse uma impureza dramatúrgico-romanesca indevidamente inserida no "documentário propriamente dito" (entendido como os segmentos cuja estilística é próxima do "documentário direto"). Porém, o uso de encenações já constituiu a prática básica de produção no documentário "clássico" (expositivo, griersoniano, de missão didática). E esse expediente permanece, contemporâneamete, sendo reutilizado de modo inovador, para instaurar relações através da enunciação, nos documentários "performativos" (La Commune"; The Corporation ; Essa é a Cara da Democracia; Uncovered: The Whole Truth about the Iraq War); para metadiscursivamente indagar sobre meios e propósitos (Verdades e Mentiras); e/ou para tematizam auto-ironizar os próprios expedientes representacionais (Name Viet, Given Name Nam).

Uma transição, muito privilegiada por boa parte da teoria pósestruturalista do cinema, é identificada como a passagem do "cinema 
clássico" ao "cinema moderno". Trata-se do surgimento do que se convencionou chamar de "cinema direto" ou "cinéma vérité". Coerentes com a mentalidade intelectual pós-Segunda Guerra Mundial, teóricos e cineastas se esforçaram por deslocar a autoconcepção dos produtores do audiovisual documentário, tirando-a da demiurgia didática da encenação de "atualidades criativamente tratadas" (Grierson) para a terapia da observação do ponto de vista de uma "mosca na parede". Nada de conduzir a interpretação do público, cada qual que aprenda o que quiser ou puder, confrontando-se com as evidências cruas dos experimentos documentários. $\mathrm{O}$ cinema direto recomenda à observação desapaixonanda da realidade social.

Esta abordagem, de inspiração existencialista, tem sido tão tantalizante para uma parte da teoria do documentário, que parece ter conduzido a uma certa negligência na demarcação das inflexões éticoestilísticas subsequentes. De outras fontes, próximas da filosofia analítica e do cognitivismo anglófono, provém a maior parte dos estudos sobre as estilísticas reflexiva e performativa. $\mathrm{Na}$ primeira, a pretensão à imparcialidade é obstinadamente colocada em suspeita, através da tematização da agência "detrás da ocular" e dos ardis da interação com os agentes "diante da objetiva". A relação de produção de saber é a parte da realidade a ser escrutinada com maior urgência (Ramos, 2005; Nichols 1994; Renov, 2004). Com o documentário performativo - que atinge o paroxismo no ciberdocumentário performativo ativista - a agência defronte a tela é também sugada para o exame metadiscursivo. Neste caso, o propósito é desenvolver poéticas políticas, ou seja experimentar, usando percepção-enquanto-expressão da comunicação audiovisual, a instauração de relações de produção e interpretação da cinamatográfica (Sobchack, 1982; 1992; Neves, 2010b).

Para compreender os conjuntos ético-estilísticos e suas translações, propomos generalizar a idéia de "métaforas da teoria" do cinema, de Vivian 
Sobchack (1992). A autora propõe que a história da teoria e dos métodos de análise de cinema seguem uma sequência de tropos. Acredito que seja heurístico considera-los também com matrizes retóricas da produção audiovisual.

\section{Primeiro tropo: o quadro}

No primeiro tropo, do quadro ou da pintura, agrupar-se-iam as enunciações audiovisuais que identificamos historicamente como "cinema clássico". É o documentário cinematográfico que emerge a partir do descarte da polissemia, da imersão urbana transitório e de performance improvisada do "cinema das origens" (Burch, 1991; Hansen, 1994; 1997; Costa, 2005; Kluge, 2009). Este arranjo produtivo conduziu o cinema (e o rádio) à sustentabilidade econômica, em moldes industriais. $\mathrm{O}$ sucesso dele seria proveniente da assemblage de um arranjo retórico terso, em que se articularam a estabilização narrativa dramatúrgico-romanesca grifftiana, grandes investimentos de capital, organização de redes de distribuição centralizadas e habitualização da apreciação espectatorial (narcótica, na perspectiva de J.-L. Baudry, [1970]).

A primeira metaformose desse arranjo aparece quando, por iniciativas interessadas na criação de formas de representação politica nãoeleitorais, realizadores quebequenses e franceses começaram a experimentar outros arranjos de produção de documentário, ainda que dentro das condições de difusão massiva e apreciação "clássicas". Isso envolveu, de um lado, uma intensiva inovação técnica nos artefatos de captação de imagens, com a apropriação de câmeras leves usadas em reconhecimento militar e de gravadores magnéticos originalmente desenvolvidos para automação industrial. De outro, houve um esforço de argumentação para sustentar as novas soluções retóricas como respostas estilística condizentes 
com uma nova ética da cidadania no pós-guerra. Discursos omniscientes e heterodiegéticos do documentário clássico não satisfaziam a demanda de meios para expressar as singularidades das experiências "existenciais" de grupos sociais marginalizados - de franco-canadenses independentistas a africanos participantes de rituais de possessão.

\section{Segundo tropo: a janela}

Da "pintura" para a "janela", o ideal estóico de observação imparcial, apelidado como "mosca na parede", jamais foi recebido sem oposição. Desde o início do cinema direto, a imersão homodiegética do observador, enquanto desautorizava pretensões a omnisciência, também torna o observador politicamente responsável pelos eventos que presencia ou mesmo cuja presença precipita. É bastante coerente com o momento histórico no qual a responsabilidade (ou culpabilidade) coletiva pela inação política severamente questionada (Arendt, [1963], 1987; Souki, 1998). O que não é corente é que o enunciador tenha permanecido detentor do privilégio de decidir sozinho quais eram momentos "decisivos" a integrar os filmes. Portanto, persistia a assimetria da relação do operator com quem está defronte às telas e/ou diante das objetivas das câmaras.

Em poucos anos - com grande ajuda do consumo dos gadgets de autoespetacularização - o tropo da janela logo foi sucedido pelo do espelho. Seguindo esta metáfora, teoria e prática do cinema empreendem uma investigação intensiva sobre a subjetividade de quem grava e da performatividade dos atos de gravar vídeos. A "mosca cai na sopa", pelas suspeitas sobre a efetiva eticidade das pretensões de universalidade de representações que não haviam deixado provir de pontos de vista individuais, situados. Por mais que o "cinema direto" estivesse imerso nos acontecimentos, na perspectiva crítica dos novos movimentos sociais, a 
pretensão docente permanece impondo uma perspectiva masculina, hetero- e monoafetivo-normativa, racionalista, eurocêntrica e monoteísta.

A partir do final dos anos 1960, a pressão política pela emancipação dos públicos abriu caminho para um longo período de experimentação de produção colaborativa, no que chamamos de "espectatorialidade reversível". Um marco da emergência dessa relação através do cinema é a película “Classes de Lutte", de Chris Marker. Nela, o cineasta (ou melhor, o coletivo Dziga Vertov, da qual Marker participava), foi constrangido a compartilhar a autoria com o ator social. O coletivo realizou um documentário sobre o movimento grevista dos trabalhadores das indústrias texteis de Besançon e Sochaux ("A bientôt, j'espère", 1967), e, em seguida o exibiu para os operários - prática distintiva do "documentário interativo".

Ao fazê-lo, os cineastas foram acusados pelos operários de explorálos, de aproveitarem-se da sua imagem para benefício próprio, e de não se comprometer com nenhum ganho para o movimento. A resposta do coletivo de Marker foi dar treinamento básico e acesso a equipamentos aos grevistas, resultando em um dos primeiros documentários que hoje chamaríamos de "comunitários".

A introdução do videotape abriu amplas possibilidades para a produção audiovisual experimental independente, como a "Guerrilla Television" estadunidense Paper Tiger Tv. Como algumas outras iniciativas surgidas no contexto da arte experimental, esta depois se tornaria parte da programação da rede "grassroots video" via-satélite Deep-Dish TV. É notável a relevância dada na programação da DDTV aos vídeos metadiscursivos sobre as mediações da televisão, da representação documentária e cinematográfica. O estilo tosco dos programas, coerentemente, visava ao máximo dar saliência aos vestígios dos processos de construção de notícias e documentários; os enviezamentos temáticos são também assumidos, supondo que o apreciador crítico irá "descontar" a parcialidade dos enquadramentos visuais e argumentativos. Quando não 
questionam diretamente os padrões mass-mediáticos, os vídeos servem para experimentar, na imersão cinematográfica, as perspectivas corporalmente inscritas de grupos sociais marginalizados, geralmente vinculados aos chamados "Novos Movimentos Sociais" (NMSs).

Essas experiências viriam a ser reverberadas nas práticas brasileiras de vídeo popular militante, que buscavam o processo de redemocratização e saída da ditadura civil-militar de 1964. Logo depois, no espírito do movimento de rádios livres comunitárias, do midiativismo radical europeu dos anos 1970 e das práticas de produção dos NMSs norte-americanos, tais experiências seriam retomadas em práticas do Vídeo Comunitário. Entre finais dos anos 1970 e meados da década de 1980, floresceu, através da Associação Brasileira de Vídeo Popular, uma vasta produção audiovisual em que colaboram profissionais, entusiastas e leigos, frequentemente pertencentes ao contexto de atores sociais periféricos, rurais, etnicamente minoritários e/ou de baixa renda.

\section{Terceiro tropo: o espelho}

A este ponto, já é possível observar a segunda translação da metáfora central da retórica audiovisual documentária, do tropo "janela" para o "espelho": já não se trata mais de contemplar uma realidade social com um distanciamento estoico que autorizaria capturar "instantes decisivos" de modo privilegiado; o empenho, então, passou a ser dedicado à autoobservação, examinando o resto do mundo atrás de si, como fundo ou cenário projetado com referência à experiência subjetiva.

A disseminação socialmente transversal dos equipamentos e das práticas de videoprodução propiciou que as imagens de um documentarismo não-profissional, "entusiástico" (Lewandowska, 2007) ganhasse cada vez mais espaço nos campos das artes visuais, do telejornal e do documentarismo (Europa em 5 minutos, 1986; Amator, 1979; Amador, 
2011). A incorporação da participação de tomadas de imagens nãoprofissionais no telejornalismo também se ampliou, de modo inexorável, entre os anos 1980 e 1990. A crescente incorporação dessas imagens nos telejornais vem se mostra politicamente decisiva para o deslocamento das representações públicas, por exemplo, dos agentes do aparato repressivo do Estado (Neves, 2000; Neves e Maia, 2008).

Além disso, ampliou-se o espaço de produções participativas experimentais na TV comercial - desde o Jornal de Vanguarda (Rede Bandeirantes, 1988-9), e Perdidos na Noite, (TV Gazeta, 1984-8) até o atual “Esquenta!", do Núcleo Guel Arraes (Rede Globo). Tais produções podem ser interpretadas como "enclaves comunitários" inseridos nas grades de programação da TV de massa. Nelas, como se pode observar no modelar Boca de Lixo $(1993)^{5}$, cria-se um fluxo comunicativo de duas camadas. Em uma, mais interna, ou "comunitária", a produção colaborativa explora a participação direta do público em várias etapas da produção e nas primeiras situações de apreciação (bem ao estilo de Crônica de um Verão, 1961), nos quais os vínculos dos participantes com localidades e grupos sociais específicos são ostentados; em seguida, as imagens desse circuito são apropriadas como produtos para a circulação massiva, agregando os ganhos retóricos da identificação pessoal entre espectadores, produtores e atores sociais.

Ao transformar o circuito comunitário em objeto de fruição estética espectatorial, legitima-se o papel dos produtores especialistas na promoção social de grupos subalternizados - os mesmos que, no resto da programação cinematográfica e telejornalística, permanecem invisibilizados. Nessa

\footnotetext{
${ }^{5}$ A produção de Coutinho cria um primeiro circuito no qual as imagens dos catadores de lixo são exibidas para eles duas vezes: primeiro, viabilizando a abordagem inicial; ao final, ostentando o cumprimento do compromisso ético do documentário progressista; porém, os registros dessa circulação são transpostos para objeto de apreciação estética, no circuito do cinema documentário. É claro que os filmes de Coutinho tem caráter político-prefigurativo, tendo sido produzidos como ferramentas para mobilização de grupos militantes e ativistas.
} 
retórica de duas camadas, há uma espetacularidade reversível - um "espelho duplo".

\section{Quarto tropo: a máscara}

Fora da TV aberta, o uso do audiovisual pelos novos movimentos sociais - de mulheres, gays, negros, aborígenes - fez emergir uma ética para a produção documentária e noticiosa que se manifesta em traços estilísticos peculiares. Espaços de visibilidade corporalmente marcados, buscam afirmar as diferenças físicas, afetivas e cognitivas dos grupos subalternizados, denunciando perceptual e discursivamente o caráter opressivo do padrão "macho, adulto, branco sempre no comando". Retomando uma discussão recorrente nos encontros da $\mathrm{ABVP}^{6}$, o dilema, para os produtores militantes, era então como se passar de uma produção de "vídeo para o povo" a um "vídeo feito com/pelo povo".

A câmera, que já havia saído do tripé para ir para o ombro, agora era passada de mão em mão. As situações de apreciação de imagens documentárias, que já haviam sido deslocadas das salas "teatrais" para os cineclubes e as salas de estar, começaram a ocorrer em muitos outros lugares: experimentais, nas discotecas, galerias e museus; militantes, nas ruas de periferia, salões de associações de bairro, sindicatos, diretórios acadêmicos, ocas e taperas. Reinterpreta-se a reversibilidade da percepção cum expressão audiovisual em experimentos de revesamento actancial: quem age diante da objetiva passa para detrás da ocular; quem estava lá, vai para defronte a tela; e os "ex-espectadores" irão se desolcar para ser

\footnotetext{
${ }^{6}$ A Associação Brasileira de Vídeo Popular é uma organização cívica surgida no final dos anos 1970, que congregava diversos produtores independentes interessados no uso do vídeo para a mobilização coletiva, principalmente ligados ao movimento de redemocratização. Depois, esses mesmos grupos e realizadores individuais deslocaram seu interesse para práticas de etnografia militante, onde o "vídeo comunitário" era empregado como ferramenta de auto-organização. (Alvarenga, 2004) A ABVP era membro de uma das primeiras tentativas de articulação midiativista transnacional, a Coalizão Videazimuth.
} 
gravados por outra objetiva ou para fazer tomadas de imagens de outrem. Nesta circulação entre as posições actanciais do ato da tomada, os sentidos dos documentários são performados pela recursão das enunciações sobre suas relações pressupostas.

Mesmo que, desde meados dos anos 1970, a disseminação de usos extratelevisivos do vídeo já tivesse irreversivelmente pluralizado a audiovisibilidade pública (Hansen, 1994), ainda em meados dos anos 1990, quem quer que abordasse um transeunte com uma camcorder e um microfone, invariavelmente seria tratado como se fosse membro de uma equipe de reportagem da TV comercial massiva. A pluralização (e fragmentação) da visibilidade pública teve que esperar que, em meados dos anos 2000, as estruturas de distribuição de comunicação ganhassem proeminência na definição da topologia da esfera pública mediática. A rigor, as estruturas de comunicação social distribuídas não são novidade: malhas urbanas, correios, sistemas de telefonia, são todos sistemas de comunicação de topologia rizomática (Galloway \& Thacker, 2007). No entanto, a desmassificação dos fluxos de comunicação pela telemática, juntamente com a ampliação exponencial da ocorrência de situações de tomada e de apreciação pela digitalização do cinema, parecem ter conduzido à redefinição das agências do apreciador, do produtor e dos atores sociais envolvidos na expressão audiovisual.

Hoje, temos uma miríade de espaços de visibilidade, cada qual dotado de sua própria eticidade estilística. Em geral, os contatos entre ambientes comunicativos eticamente heterogêneos são marcados pela crueldade (Stoller, 1992) e pela "transculturalidade" (Tomas, 1996). Quando todos dispôem de câmera e detêm uma emissora no bolso, ninguém mais sabe aonde (e quando) vão parar as imagens captadas. Para o bem e para o mal, a produção audiovisual documentária tem mostrado uma forte tendência para superar a metáfora do espelho em favor de outro tropo - o da máscara. 
Neste caso, não se atribui à máscara o significado de disfarce. O anonimato ou camuflagem contra a repressão são propósitos estratégicos efetivos, mas além deles, há uma positividade de pseudonimato do contracampo da imagem-câmera ativista, como marca do pertencimento a uma visibilidade contrapública, performance de instauração de personce coletivas, e manifestação de compromissos com accountabilities não referidas à esfera pública burguesa. Nas situações de protestos de rua, os vídeo-ativistas vêm criando formas ad-hoc de organização, utilizando as câmeras como máscaras coletivas. Ao filmarem-se uns aos outros, os manifestantes-cinegrafistas coíbem a brutalidade policial. Caso contrário, os vídeo-ativistas não são capazes de usar as câmeras como "imperativos categóricos à bateria" e se encontram isolados e se tornam alvos prioritários da brutalidade. Captados uns pelos outros, porém, resistem com corpo autoperceptivo. Tal como outros mascaramentos (capuzes, pseudônimos) o vídeo-ativismo tem propiciado a instauração de agências políticas coletivas que coalescem como representações políticas contrapúblicas. A expressão disso, como vimos, ocrrre desde o nível pré-reflexivo. A exploração performativa da reversibilidade entre expressão e comunicação é indispensável, porque fornece o fundamento perceptual para os experimentos ético-políticos que pretendem contrastar à repressão biopolítica, (Neves, 2010b).

Hackativistas conhecem-se uns aos outros pelos pseudônimos e/ou pelo estilo de suas ações (Samuel, 2004). A metáfora da máscara expressa uma retórica documentária da despersonificação e da coletivização das identidades públicas. Seu propósito é permitir que o cidadão, literal e simbolicamente, imerja em outras pessoas, ou funda-se com outras. Chelsea Manning, Edward Snowden, Aaron Schwartz, Julian Assange, todas as colaboradoras do Wikileaks, só puderam atuar como defensoras da democracia por poderem se passar por funcionárias obedientes, que 
secretamente investiram-se da função de delatoras dos abusos da repressão biopolítica global.

Assim como com o voto secreto, preconizado pelo ocidente como sistema "livre e justo" de eleição de representantes e governantes, atualmente, só no anonimato da máscara, diante e detrás das câmaras, que o cidadão se permite manifestar na rua sem temer perder seu emprego, ser perseguido na rua ou ser expulso de casa. Qualquer um, "câmaramascarado" se investe do olhar da multidão, com o qual pode ousar agir como vigilante do interesse público, acreditar poder abordar quem quiser, conversar ou constrangê-lo(la) a se calar. Sente-se autorizado a entrar em lugares em que não entraria sem uma autorização burocrática prévia. Podese arriscar o próprio corpo individual para transportar o olhar da câmera para pontos de vista inseguros, desde que a câmera-máscara seja também multitudinária.

A situação do cinegrafista "amador" (ou "autodependente", como preferimos, seguindo sugestão de Herzog, 2005), é virtualmente a mesma de qualquer cidadão indignado que use do anonimato, do pseudonimato ou de denominações coletivas para delatar organizações funcionários, políticos, empresas e governos criminosos. O Ho Boulemenos ("cidadão interessado") hoje dispõe de recursos comunicativos para se investir da função de watchdog, contribuindo de modo decisivo para o levantamento investigativo e consolidação de informações dispersas de relevância política. ${ }^{7}$

\footnotetext{
7 Vide, por exemplo, o projeto Free the Files, em que os reais gastos em campanhas eleitorais são apurados por uma multidão de colaboradores (Zamora, 2012).
} 


\section{Sondando a nova ético-estilística: Interatividade, "investigativismo" e colaboração}

As poéticas de mobilização do público para o fornecimento de dados, material audiovisual, narrativas, equipamentos e até dinheiro vêm deixando de ser um traço meramente desejável (para aumentar a variedade de fontes) ou um ardil sedutor (de reforço da identificação entre públicos e produtores audiovisiuais). Para a produção de noticiários e documentários, tornaram-se práticas de pré-produção tão fundamentais que, em alguns casos, ocorre uma inversão: os vídeos de autoria circunscrita servem de ferramentas precursoras para mobilização da produção colaborativa. Começando com um vídeo "viral", desencadeia-se uma campanha em redes sociais convocando o envio de material relevante ou a produção dele por voluntários; termina-se por consolidar esse material em um documentário cibertextual (Aarseth, 1994; 1997).

Este material, mesmo que se preste a ser arrematado como enunciado linear para a circulação televisiva e cinematográfica massivas, permanece como um work-in-progress. Os arranjos de enunciação dos ciberdocumentários - da produção, à apreciação e à crítica - convergem para os arranjos de programas noticiosos interativos, deixando se ser concebidos como produtos acabados, mas como processos de condução de fluxos de informação (ou criadores de enlaces de representação política). Os produtos se convertem em ambientes de interação para agentes autodependentes, constituindo redes que conduzem desde a definição dos argumentos e o design de interface das produções, até o financiamento, a divulgação e a organização de espaços de apreciação coletiva.

Embora esse modelo possa causar alguma insegurança para as definições deontológicas de jornalistas e cineastas, o trabalho do telejornalismo e do documentarismo autoral, longe de se tornar obsoleto, continua altamente especializado. A diferença é que a ênfase do trabalho se 
desloca para a capacidade dos profissionais (e/ou ativistas organizados) de orientar a mobilização, interpretar as argumentações entrelaçadas nos eventos como organização dos fluxos de imagens e relatos, e de criar estruturas de navegação e de observação das implicações éticas do design. $\mathrm{O}$ ofício do comunicador profissional, para isso, precisa superar sua identificação como escultor das narrativas e se redefinir como análogo ao dos arquitetos,urbanistase projetistas de espaços.

Produções audiovisuais abertas e colaborativo-participativas aumentam em número e diversidade. Entre 1999 e 2010, a rede de coletivos Indymedia no Brasil foi catalisada pela circulação de vídeos como A20 Não começou em Seattle, não vai terminar em Québec. Este ciberdocumentário ativista foi exibido à exaustão em centros acadêmicos, associações de bairro, sindicatos e nas ruas, para fins de catálise da organização de coletivos midiativistas.

No mundo, com propósitos semelhantes, foi produzida uma série de ciberdocumentários de Anti-Summits: Showdown in Seattle e This is what Democracy looks like (Big Noise Filmes, Indymedia, 1999), sobre os protestos que levaram a reunião da Organização Mundial do Comércio, em Seattle, ao colapso ${ }^{8}$. Rebel Colours (Indymedia, 2001), exibe a diversidade de táticas dos protestos em Praga. Genoa Red Zone (Indymedia, 2002) detalha a covardia da "ratoeira de Berlusconi”, tornando a violência contra os manifestantes antiglobalização um motivo para a persistência dos ativistas. Miami Model denuncia a militarização e o racismo da repressão nos protestos contra o encontro da ALCA, em 2003. A Kankoon/Km 0, sobre os protestos contra a reunião da OMC em Cancún, ambos produzidos em 2003, vão na mesma toada: partilhar dos riscos e dos sofrimentos corporais dos manifestantes. Além da contrainformação, todos esses vídeos

\footnotetext{
${ }^{8}$ Realizado a partir da contribuição de centenas de vídeo-ativistas, coordenados a partir do primeiro Centro de Mídia Independente, produzindo a contrainformação sobre os protestos de 1999.
} 
visam a imergir corporalmente os apreciadores nas experiências contrapúblicas. Implicitamente, acusam a falta de responsabilidade política dos "espectadores", diante do ativismo pressuposto aos "usuários".

Como mostra Chuck Tryon (2011), a nova retórica da pluralização da autoria e colaboratividade das produções documentárias ultrapassa largamente as redes ciberativistas altermundistas radicais, aparecem em arranjos de enunciação que podem ser mainstream, como Uma verdade inconveniente (2006). Documentários audiovisuais são, em geral, parte de mobilizações ativistas transmidiáticas, que incluem performances em espaços urbanos, websites, uso de plataformas de mobilização (como Avaaz, Article 19, TakePart.com, MoveOn.org) e customizações de sites de redes sociais de grande popularidade. Documentários como A Era da Estupidez (2009) Uncovered: The War on Iraq (2004) foram produzidos com recursos financeiros levantados em house parties, que também serviram para distribuí-los e promovê-los. De maneira semelhante, 99\% Occupy Wall St. Collaborative Film (2013) e The Corporation, criaram sites para a mobilização coletiva. Este último, um libelo contra o abusivo direito das corporações, foi relançado como DVD com mais depoimentos e documentos, voltando a pedir contribuições financeiras dos cidadãos interessados. Esse tipo de documentário pode ser orientado para a mobilização de públicos heterogêneos em torno de uma temática que se quer tornar comum, qualquer que seja ela. Não servem só "às esquerdas". Documentários instauradores de contrapúblicos podem ser manobrados por grupos de pressão reacionários, como em "Expelled: No intelligence allowed"9 (Tryon, 2011).

Esse novo conjunto ético-estilístico, de arranjos de produção apoiados no crowdsourcing, vem se consolidando como alternativa eficaz de produção audiovisual autodependente para a realização de documentários

\footnotetext{
${ }^{9}$ Documentário que defende o criacionismo biológico criando uma rede de promotores do vídeo e apoiadores da causa.
} 
on-line, incluindo documentários interativos. Trata-se de um modelo convidativo também para a produção de noticiários e documentários da televisão digital interativa, por produtores independentes ou por empresas de comunicação de massa. No entanto, no caso destas, costuma haver conflitos de interesse difíceis de superar, entre eles a resistência resultante da cultura profissional de jornalistas e teledifusores, que se apegam ao seu lugar de "heroís modernos" (Sontag, 1981). Documentários “crowdsourceados” não são apenas contrainformação, mas exercícios de uma poética de prefiguração política na qual o caráter performativo do audiovisual busca a instauração de contrapúblicos (Neves, 2010b; 2012).

\section{Ciber-o QUÊ?}

Como já vimos (Neves, 2012), boa parte dos arranjos documentários transmidiáticos acaba expressando, na superfície textual linear, algum tipo de personificação de uma interação de acesso aleatório sobre arquivos. O acesso aleatório, por ser inviável na linearidade dos arranjos massivos de apreciação cinematográfica e televisiva, é projetado, como uma sombra, tal como em um desenho bidimensional se representa a tridimensionalidade de um cubo ou pirâmide.

Para a experiência do cinéfilo e do telespectador, a navegação interativa com as imagens é como uma viagem na quinta dimensão física difícil de imaginar, impossível de experimentar diretamente. Para usuários de sites de videosharing ou para gamers, o caso é outro: o acesso aleatório é a relação esperada com o hipertexto - uma affordance de apreciação da qual ele sentirá falta. Se é provável que os padrões de apreciação estejam em transição entre um conjunto de hábitos e outro, cabe, o quanto antes identificar quais seriam as questões ético-estilísticas mais decisivas, em termos da implicitação do leitor no texto. 
Qual é a dimensão política da implicitação do enunciatário de documentários não-lineares, considerando os efeitos performativos dessa pressuposição? A teoria de Sobchack $^{10}$, pertinente à enunciações cinematográficas lineares e atenta relações, mediadas pelo cinema, entre apreciadores e operadores, com pouco interesse pelos "personagens", parece pouco adaptada para responder tal indagação. Recorreremos à teoria do cibertexto, de Espen Aarseth (1994, 1997), num esforço de sondar os sentidos ético-políticos da imersão cinematográfica nas condições do audiovisual interativo.

Aarseth propõe seis critérios para a caracterização das propriedades topológicas de textos: (a) topologia textual, (b) dinâmica, (c) determinabilidade, (d) transiência, (e) manobrabilidade e (f) funcionalidade de usuário. A partir destes fatores, a teoria "ergódica" do texto identifica, muito sinteticamente, quatro categorias pragmáticas básicas. Entre as ilimitadas combinações desses fatores, encontramos na prática algumas textualidades mais recorrentes:

(a) o texto linear simples;

(b) hipertextos;

(c) cibertextos determinados

(d) cibertextos indeterminados.

Observa-se, nesta lista, um crescendo de participação do enunciatário: começando com a leitura "desobediente" do texto linear, passando para os textos nos quais as escolhas de percurso são livres, mas o conteúdo e estrutura são fixas; destas, aos textos nos quais o intérprete desempenha os papéis no texto (como apreciador de Le Challenge, posto para "jogar" como jornalista investigativo). ${ }^{11} \mathrm{O}$ paroxismo da

\footnotetext{
${ }^{10}$ I. e., sobre a comunicação cinematográfica realizar-se através da imersão do apreciador no "olhar da câmara", na qual percepção e expressão se tornam reversíveis, desprivatizando e desindividualizando a percepção corporal. (Sobchack, 1992).

11 "Le Challange", (Matthieu Belghiti, Arnaud Dressen e Lætitia Moreau, 2009) é um webdoc do Canal Plus e da HonkyTonk Filmes, no qual o usuário "entra na pele" de um
} 
interatividade estaria em expressões nas quais os usuários imergem em um fluxo discursivo imprevisível, participa ao mesmo tempo e em interação com outros usuários fornecendo de segmentos textuais, redesenhando o "mapa" dos percursos navegáveis e as affordances de interação. No momento atual, este extremo só é exemplificado na web ciberativista, único tipo de texto on-line no qual os usuários são convidados (todo o tempo) a fornecer material, a difundir o vídeo, a participar de decisões sobre a estrutura e o uso das plataformas, e a colaborar com a programação (Coleman, 2004; 2012).

Retomemos os fatores elencados por Aarseth, explorando algumas das possibilidades de combinação no documentário audiovisual interativo (online e televisivo):

(a) Considerando as variações topológicas, notaremos que mesmo os textos lineares podem propiciar ou coibir a embreagem do enunciatário no texto. No caso do cinema, isso ocorre na imersão do espectador no filme, seja através das identificações com corpos figurativamente representados, seja na imersão do apreciador na perspectiva dos operadores de tomada de imagens. Como quer que isso aconteça, por mais que os objetos gerados nos atos de apreciação possam mudar ou diferir de um apreciador para outro, os textos, enquanto coisas, continuam idênticos. Não é o que acontece em topologias textuais não lineares: cada apreciação gera concretamente uma variação textual. Em um gradiente, o apreciador e/ou o próprio texto podem: alterar a ordem da expressão de segmentos textuais; mudar as conexões entre eles; acrescentar ou deletar conteúdos; redesenhar a interface de interação; alterar a perceptibilidade dos apreciadores às mudanças de percurso; e assim por diante. No limite, com cibertextos indeterminados, até mesmo a existência do texto está à mercê das decisões do público.

jornalista investigativo o qual, através da navegação nos segmentos audiovisuais, vai compondo uma reportagem sobre os dilemas socioeconômicos da exploração de petróleo no Equador. ( http://www.canalplus.fr/pid3400.html) 
(b) No quesito dinâmica, ou seja, se um texto pode ou não "crescer", isso pode ocorrer com o número de segmentos textuais (dinâmica intertextônica) ou com a extensão desses segmentos (dinâmica intratextônica). É evidente a relevância política para o documentário interativo, porque define o grau de participação do público na modificação de estruturas e conteúdos. Isso se refere à (a) presença das affordances de participação, ou seja, da capacidade cedida aos usuários de acrescentar, retirar ou reestruturar o material, (b) perceptibilidade das affordances, no caso, a transparência das ferramentas de interação para as citadas operações; (c) operabilidade efetiva desses controles para diferentes usuários. ${ }^{12}$

(c) A categoria da determinabilidade serve para caracterizar as relações de "vizinhança" entre segmentos textuais, ou seja, se elas podem ou não variar, se os percursos de navegação são fixos ou mutáveis. As questões ético-políticas da participação do enunciatário são semelhantes às mencionadas acima. A observação empírica sugere que, quanto mais são transformáveis os percursos, mais facilmente uma maior diversidade de usuários irá explorar criativamente a interpretação. Aparentemente, maior dinâmica e indeterminabilidade textuais são traços típicos de textualidades associadas a modelos progressistas de participação democrática (Shaw \& Benkler, 2012). Porém, como citado no caso de Expelled, não há relação necessária; a organização de arranjos de participação com propósitos reacionários é perfeitamente viável - principalmente para mobilizações distribuídas (Gallaway \& Thacker, 2007; Velkhen, 2013).

(d) Quanto ao fator transiência, a questão da sincronia ou dissincronia do fluxo audiovisual é decisiva para a diferenciação entre documentários interativos on-line e noticiários televisivos interativos. Para que os documentários telemáticos sejam apreciados, pelo menos a maioria das

\footnotetext{
12 Sobre as implicações ético-políticas das affordances, ou seja, dos "propiciamentos" de agências definidos pelo design de interação com o texto e entre os sujeitos através dos textos, cf. Bendor et al., 2012; Bardonne, 2010; Magnani \& Bardone, 2008.
} 
sequências e planos deve estar disponível para a apreciação não-linear. No caso dos programas em TVdi - pelo menos considerando a memória local limitada dos set-top boxes definidos pelo padrão brasileiro, e também a velocidade de transferência de dados, apenas uma parte do material pode estar imediatamente disponível para acesso aleatório. É, porém, possível criar arranjos de TV digital interativa (TVdi) em que os teleusuários possam selecionar, através de canais de retorno simples, quais segmentos textuais passaram a ser transmitidos utilizando-se o sistema de carrossel. Mesmo assim, é preciso solucionar uma interface coletiva, que faça com que escolhas individuais do que transmitir sejam agregadas, definindo que novos segmentos serão disponibilizados pela emissora. Por outro lado, é possível criar formas híbridas de webdocumentários interativos-programas de televisão-aplicativos de celular, de forma que o material não disponível no sinal de TV possa ser acessado on-line e eventualmente indexado à informações do usuário (geolocalização, personalização a partir de preferências de uso, idioma, et al.). Uma possibilidade interessante da TVdi é a de desenvolver arranjos para realizar transmissões em "sincronismo defasado", nas quais haveria um lapso de tempo entre a captação das imagens e sua difusão. Neste pequeno atraso, poderiam ser incorporadas informações e imagens complementares para acesso opcional do teleusuário, como uma TV de "realidade aumentada". ${ }^{13} \mathrm{O}$ sincronismo entre a exibição e a apreciação permite um crowdsourcing em tempo real, com o próprio público atuando como "diretor multitudinário de TV". ${ }^{14}$ Dadas as

\footnotetext{
13 Por exemplo: colocando material textual e audiovisual de referência para esclarecer assuntos, obras ou autores citados em um debate; indicando e dando acesso a canais de participação política em notícias que envolvam denúncias; ou realizando e apresentando resultados sondagens de opinião ao longo de programas.

14 Uma das mais surpreendentes experiências audiovisuais documentárias da “automobilização cívica" brasileira de meados de 2013 resultou da articulação entre o uso de serviços de streaming de áudio e vídeo em alta resolução a partir de dispositivos móveis, e o de mensagens instantâneas (como Tweeter, Telegram, Whatsapp). Usando o arranjo, midiativistas de variados graus de amadorismo e profissionalização fizeram uma cobertura das manifestações de 2013 sem qualquer sistema centralizado de coordenação, "subindo"
} 
características do sistema de transmissão de TV digital brasileira, através de soluções narrativas e de interface, notavelmente promissora, é concebível a criação de arranjos de ampla participação dos públicos em transmissões ao vivo de eventos, com imagens de múltiplas fontes (amadoras e profissionais) e com controle feito pelas conversações síncronas dos participantes dos eventos e/ou do público teleusuário. ${ }^{15}$

(e) Aarseth descreve, com sua categoria manobrabilidade, a maneira como o apreciador pode realizar saltos entre segmentos textuais. Em um extremo, está o acesso aleatório pleno - é o caso dos acervos de vídeos indexados por tags e metadados, de bibliotecas e arquivos on-line, como em projetos como o Museu da Pessoa, ou o Internet Archive. Esse tipo de acesso é possível em webdocs interativos, mas aí o trabalho poético sobre a estrutura de percursos de interação emagrece até se limitar ao design de um mecanismo de buscas, que permita cruzamentos de dados ou visualizações de metadados, usando agregações estatísticas ou sistemas de recomendação. Algoritmos de recomendação de proprietários, como os que operam "por trás" dos sites corporativos de videosharing (Youtube, Vimeo, Dailymotion et al.) são quase o extremo oposto do acesso aleatório pleno. Tornam o acesso controlado e controlador, já que todos os comportamentos dos usuários são registrados e acrescentados a agregações estatísticas e perfis aos quais jamais temos acesso. A implementação de navegação de acesso

os vídeos para servidores de streaming enquanto recebiam sugestões e dicas de outros participantes das manifestações através de mensageiros instantâneos.

${ }^{15}$ Hoje, um aparelho com capacidade de produção de imagens full HD, e de upload dessas imagens, custa menos de mil reais (500 dólares ou 300 euros), e permite que qualquer cidadão politicamente interessado e disposto a algum aprendizado técnico - na configuração do serviço de streaming, em geral através do tweetcast - atue como cinegrafista de uma transmissão ao vivo para o público amplo - eventualmente, massivo. Transportando o público usuário para a experiência vicária dos riscos derivados da produção das imagens em situações de indeterminação normativa extrema (como em protestos ou festas de rua), os cinegrafistas-manifestantes reinventaram o telejornalismo de cobertura de eventos, não somente pela corporificação e na incorporação da subjetividade a cada perspectiva de fluxo de imagens, mas pela construção de uma nova experiência multitudinária de "publicalidade". O estatuto público dos acontecimentos passa a ocorrer com a expansão da reflexividade da sua representação audiovisual. 
aleatório pela TVdi tende a exigir grande engenhosidade, porque como já vimos, é preciso carregar o material de um arquivo extenso para o carrossel, e dele para a memória local do teleusuário, a partir de alguma solução de "quem decide" o que transmitir. Soluções de manobrabilidade estilisticamente mais sedutoras, como a inserção de links condicionais ou links escondidos ${ }^{16}$ permitem diversas formas de articulação, poeticamente promissoras. Assim, o acesso à participação em um programa pode ser condicionado ao acesso a determinado material de referência; ou a acumulação de escolhas de determinado tipo pode levar à disponibilização de segmentos audiovisuais variados.

(f) Finalmente, sob a rubrica funcionalidade de usuário descreve-se a capacidade do usuário de explorar um acervo, performar um papel na narrativa, configurar a estrutura de navegação ou o conteúdo do texto e poetizar intervindo de modo criativo no cibertexto. É relativamente fácil implementar tais funcionalidades em webdocumentários, porque o acesso aleatório é geralmente um pressuposto da navegação. Para a TVdi, porém, sua implementação exige um esforço de inovação no arranjo produtivo, sendo necessário desenvolver aplicativos específicos para criar canais de retorno simples e pleno. Sem estes, não seria possível nem a seleção de trechos, nem a remissão de contribuições de material audiovisual, pelo público.

Pode-se observar nos documentários crowdfundeados já existentes uma dissimetria entre um público que tem o privilégio de configurar a estrutura e de desenhar os ambientes de interação e os demais, que, no máximo, acessam a configuração de conteúdos. Do ponto de vista políticodemocrático, práticas de circulação entre membros desses dois estratos de participação seriam recomendáveis; do ponto de vista da sofisticação

\footnotetext{
${ }^{16}$ Os links condicionais aparecem apenas para alguns usuários com características tais e/ou que tenham percorrido outros segmentos textuais; os escondidos são inadvertidamente acionados por comportamentos dos usuários, e são implementáveis tanto em webdocs interativos quanto em programas de TVdi.
} 
poética, não necessariamente. É possível, como em Le Challenge, superpor o papel do explorador e do performer; mas, como nos tweetcasts das manifestações de 2013, ou nos vídeos ciberativistas dos anos 2000, é possível ir bem mais longe: pode-se realmente persuadir os apreciadores a atuar como participantes da enunciação, seja produzindo material, seja criando situações de apreciação. ${ }^{17}$

Os quatro graus de interatividade delineados por Aarseth são convergentes com os modelos de produção propostos por Luís Soares (2013), um dos desenvolvedores do middleware Ginga da TV Digital brasileira. Porém, os dois últimos formatos de programas, delineados por ele, e que teriam o maior grau de interatividade e ampla participação dos teleusuários são justamente aqueles menos confluentes com os interesses de emissoras comerciais e fabricantes de equipamentos.

Soares descreve o penúltimo grau de participação dos usuários sob o título Aplicações utilizando a tela principal conjuntamente e relacionada com o significado do programa de TV, e também sincronizada com esse conteúdo audiovisual. Trata-se de arranjo de produção e uma poética ainda inteiramente inexplorados. Sua concretização demandaria um desenho de produção que incluísse, como elemento fulcral, a participação dos teleusuários. Para isso, é pressuposto que "o produtor do conteúdo principal já o faça sabendo das possíveis não linearidades, e o faça induzindo e estimulando essas não linearidades, fazendo do telespectador parte do seu conteúdo". Trata-se de um modelo no qual a implicitação do enunciatário é diretamente articulada com a imersão audiovisual. Neste caso, ela é posta em uma relação de revesamento concreto, (e não apenas vicário), tornando, persistentemente, o público parte do assunto da programação.

${ }^{17}$ É intrigante que, na literatura sobre TVdi e webdocs interativos, a poética da apreciação coletiva, na qual os percursos interativos não lineares são realizados em grupo, seja tão raramente explorada. Quase sempre pressupõe-se uma apreciação espectatorial, por intérpretes individuais. Uma experiência pioneira nesse sentido é a videoperformance de navegação dialógica por "excertos" de atos de desobediência civil, do A.N.T.I. Cinema / Projeto Mutirão, de Graziella Kunsch. 
O último grau de intensidade na participação do público teleusuário seria encontrado, para Soares, no formato chamado "Narrativas Interativas", que se constituiriam em "narrativas em que o telespectador não só tem a possibilidade de agregar conteúdo adicional ao programa principal, mas também tem a possibilidade de mudar o fluxo desse programa, conforme seu desejo". Aqui, o teleusuário toma decisões de produção (ainda que limitadas àquilo que a pré-produção possa ter preparado). O coinventor do Ginga afirma que se trata de um tipo de produção de custos proibitivos, com os altos riscos de uma produção muito inovadora. No entanto, que seja apenas no caso de permanecermos pressupondo um tipo de produção industrial. Concebendo modelos de produção intensivamente distribuída, efetivamente realizada por um público amplo, os custos seriam minorados e os riscos, também, já que os participantes seriam diretamente interessados na apreciação do material em cuja produção estariam envolvidos de modo decisivo.

\section{Complementaridades entre webdocs e Tvdi}

É espantoso que a maioria das sugestões de formatos de programa para a televisão digital interativa, disponíveis na literatura recente, sejam representações audiovisuais de eventos para os quais não há nenhuma necessidade prática de não linearidade interativa, ou seja, de mudança do curso das ações pela participação do público. Trata-se de práticas sociais de desenvolvimento lineares: eventos esportivos e teledramaturgia folhetinesca. ${ }^{18} \mathrm{~A}$ interatividade se limita à transmissão de imagens de pontos de vista distintos sobre os mesmos acontecimentos, ou à inserção de propagandas comerciais e de outras formas de "realidade aumentada" televisiva. O exemplo recorrente da telenovela de enredo interativo, é, em

${ }^{18} \mathrm{O}$ exemplo mais recorrente dado pela literatura sobre a TV Digital brasileira é o da cobertura de partidas de futebol e de outras competições esportivas. 
última análise, redundante. Como boa parte do público telespectador de novelas sabe ou desconfia, o processo de produção da teledramaturgia atual pressupõe uma atenção voltada aos levantamentos de opinião pública, por grupos focais e surveys, sobre o impacto da evolução das intrigas na audiência. Em certo aspecto, a telenovela brasileira já é, há muito tempo, um gênero audiovisual interativo de massa. Nada disso faz com que os enredos se tornem menos previsíveis e eivados de valores não submetidos à discussão franca. A informação sobre os juízos dos telespectadores não é uma participação dos públicos, e as intrigas seguem uma linearidade de dar inveja a qualquer morfologia do conto maravilhoso. É de se esperar que, por si só, a interatividade da TV Digital não faça do telespectador um teleusuário participante. Há muito o que se pensar a respeito de poéticas de participação na interatividade televisiva.

A mais importante inovação poética que pode ser viabilizada pela TV digital interativa, encontra-se já experimentada pelos documentários transmídia: a construção participativa e interativa de narrativas não lineares. A transmissão aberta da TV reside na otimização da interação dos teleusuários sobre o curso dos acontecimentos teledifundidos, pois permite que seja síncrona ou em tempo diferido, móvel e com possibilidade de transmissão de imagens a partir de aparelhos do público.

A TVdi permite contornar algumas limitações dos i-docs. Primeiro, de cunho técnico: largura de banda e instabilidade dos streamings via web, quebrando a imersão do narratário com imprevisíveis e intermináveis “carregando..." (análogos ciberaudiovisuais dos filmes queimados nas salas de cinema, ou dos "problemas técnicos" das transmissões de TV analógica). Segundo, de caráter topológico-textual: a apreciação via web é individualizada e tendencialmente fragmentadora, pois a experiência não permite ao enunciatário engajar-se em uma apreciação que permita supor uma reflexividade massiva como a da transmissão de TV. Terceiro, limitações retóricas: a interação se limita à navegação em um hipertexto de 
conteúdo e estrutura fixa, pré-determinada pelos produtores profissionais (hipertextual); e raramente, os i-docs permitem uma participação de construção, seja na incorporação (ou exclusão) de segmentos textuais, seja na modificação da estrutura de conexões, seja no interfaceamento (ou seja, cibertextual).

Essa otimização da experiência imersiva é mais provável no caso de a TVdi efetivamente permitir flexibilidade em termos de linguagens de programação de aplicativos, controle da exibição de material semicustomizada pelo teleusuário e recursos de bidirecionalidade. A situação, no Brasil, é ainda bastante indefinida, com padrões abertos sem ferramentas de produção abertas e com poucos laboratórios para testes de transmissão. Provavelmente, a menos que os teledifusores invistam na produção de hardwares e aplicativos que viabilizem a recepção interativa com canais de retorno plenos, a indústria e as emissoras comerciais fazem lobby contra a interatividade. Por exemplo: por lobby das indústrias de eletrônicos, o padrão aprovado para a construção dos set-top boxes, atualmente, não prevê o acesso à conexão wifi. As caixas estão especificadas para dispor de $2 \mathrm{~Gb}$ de memória, mas não para o armazenamento do streaming de imagens, pois o aparelho de recepção não é veloz o bastante para gravar, reproduzir e transmitir imagens de alta definição. Ainda não está claro se serão possíveis expansões de memória nos set-top boxes, mas é possível usar padrão de transmissão de TVdi em computadores e smartphones, criar recursos de hardware e software, tornando a capacidade de armazenamento de imagens para navegação não linear praticamente ilimitada.

Por outro lado, é preciso questionar o pressuposto de que os atos de apreciação são necessariamente individualizados. Usando o sistema de transmissão de dados por carrossel, pode-se conceber, por exemplo, programas de interatividade massiva, ou de interatividade de grupos locais, nos quais os teleusuários navegariam juntos, explorando acervos 
virtualmente ilimitados de imagens. A questão técnica e poética, para formatos interativos massivos, parece ser desenvolver procedimentos de agregação de escolhas individuais por canais de retorno de interatividade simples (textos curtos) que guiem a teledifusão do material.

O modelo de apreciação televisual tampouco precisa se limitar às situações de apreciação domésticas, familiares e privadas. É possível criar arranjos de apreciação coletiva local, com capacidade ampliada de armazenamento e de conexão - ampliando a imersividade e a navegabilidade das imagens. A experiência do vídeo comunitário e ativista mostra que é altamente produtivo, em termos de mobilização coletiva e de experiência estética, criar ocasiões de apreciação coletiva de materiais para a apreciação de programas especialmente desenhados para isso. Que isso possa não ser de interesse direto das corporações privadas de comunicação, não exclui a possibilidade de uso por empresas públicas de comunicação e canais de parlamentos e tribunais, como ferramenta de e-participação política cidadã em debates interativos sobre decisões polêmicas em tramitação em parlamentos, na definição de políticas do executivo, em audiências públicas de parlamentos e tribunais, na criação de minifóruns deliberativos e em consultas populares, como já ocorre nas experiências de orçamento participativo on-line.

É concebível, através do uso das possibilidades de uso do middleware Ginga, que se obtenha:

1. A manutenção de continuidade diegética no fluxo de imagens (ou seja, a largura de banda da TV digital é fixada em aprox. $20 \mathrm{Mb} / \mathrm{s}$, o que evitaria a quebra de imersão do "loading..."), permitindo uma fluência na navegação não linear que é impossível (ou de custo proibitivo) na apreciação interativa doméstica via internet;

2. O aprofundamento da bidirecionalidade dos fluxos comunicativos, experimentando arranjos de revesabilidade nos quais os usuários poderiam circular entre as posições actanciais da representação audiovisual (diante da 
objetiva, detrás da ocular, defronte à tela), através da exploração dos canais de retorno para interatividade simples (para envio de votos, de mensagens de texto e de comandos) e plena (upload de imagens)

3. A conquista de uma reflexividade pública ampla, de massa, para a visibilidade de programação não linear interativa, com implicações políticodemocráticas notáveis, já que é bem plausível que o "precipitado" das conclusões dessas práticas de participação política terá impacto efetivo sobre as escolhas de voto, consumo e na formação de gosto.

Nas histórias das batalhas, as controvérsias sobre quem pode narrar o que e como chegam às vezes a eclipsar os próprios eventos. É, hoje, altamente improvável que algum indivíduo particular venha a ter sucesso ao pretender oferecer testemunhos mais válidos do que o de outros; ou que possa ser julgado incomparavelmente mais hábil na produção de uma síntese dos testemunhos particulares. Por isso, documentarista algum escapa de ser desautorizado em quando manifesta tais pretensões, ainda mais que a perspectivação não mais "necessita" ser necessariamente singular. A proposição de arranjos de interpretações múltiplas, através do uso de artefatos lógico-retóricos, tornou-se uma escolha viável para os comunicadores profissionais e para o próprio público. Do ponto de vista democrático, é recomendável aproveitar todas as condições que permitam que a narrativa dos eventos públicos seja plural e passível de ser perscrutada através do percurso não linear dos públicos. Há um surplus democrático na auto-observação coletiva de interseções entre as perspectivas subjetivas corporalmente inscritas nas tomadas de imagem.

A democratização prometida pela difusão de documentários interativos também se refere ao caráter economicamente redistributivo da produção audiovisual, na medida em que ele for desenvolvido como uma tecnologia aberta (com licenças abertas e/ou libres). Esta escolha política tornaria a produção de i-docs e TV digital interativa (TVdi) um vetor de 
geração de novas oportunidades de negócios de valor agregado, de trabalho de alta produtividade, e geração renda local, para os países latinoamericanos (Soares e Baum, 2012).

Este conjunto de fatores torna o desenvolvimento de produções televisuais interativas acentuadamente propícia para canais públicos, universitários, comunitários, judiciários e legislativos, e pela produção de instituições não organizadas para a obtenção de lucros comerciais (Tozzeto, 2012). O programa Brasil 4D tem sido uma iniciativa pioneira neste sentido, priorizando o acesso a serviços públicos básicos (Barbosa Filho, 2015). Trata-se da oportunidade única (e da tarefa urgente) de inventarmos práticas anteriormente inexistentes de teledifusão audiovisual, não apenas de arranjos produtivos ou de modelos de negócio mas, principalmente, em termos ético-estilísticos. Como veremos, muitas dessas inovações já se encontram dispersas como experimentos de documentários “crowdsourceados”, mídias comunitárias, midiativismo e nos documentários imersivos, interativos e cibertextuais. ${ }^{19}$

\section{Procedimentalização: proposições, jogos de improvisação e poéticas ciberaudiovisuais transmedia}

Nesta seção faremos algumas observações sobre peculiaridades das poéticas da interatividade. Referimo-nos, especialmente, à feliz descoberta da pesquisa sobre métodos de improvisação para o aprendizado de uso de meios de expressão audiovisuais. A notável contribuição do uso de procedimentos de criação, convergindo práticas de aprendizado teatral e de arte contemporânea (Spolin, 2005; Clark, 1997; Neves, 2000), emerge por sua eficácia também como prática de experimentação radiofônica e audiovisual. A transcriação de jogos de improvisação e proposições para a

\footnotetext{
${ }^{19}$ Para uma discussão de fôlego sobre cibertextos, dentro de um quadro mais amplo de topologias textuais, ref. Aarseth, 1994, 1997.
} 
aquisição coletiva, não coercitiva, de habilidades de comunicação e expressão poética, tem resultados que ultrapassam o "domínio da linguagem" ou "gramaticalização para os meios", propiciando inovações poéticas imprevisíveis, no uso do audiovisual. Entre as descobertas do uso de procedimentos de invenção, esteve a decorrente da observação de usos "desviantes" dos protocolos (regras dos jogos), afastando-se de uma utensiliarização do audiovisual como para a função estrita de transmissão de informações. Neste caso, as situações experimentais conduziam a resultados poéticos muito próximos daqueles obtidos através de proposições artísticas e da realização de protocolos de arte conceitual. ${ }^{20}$

Dispensando proximidade geográfica ou empenho de recursos vultosos, há um vasto campo de experimentação na combinação de procedimentos lúdicos de produção com mobilização de públicos para colaboração na produção audiovisual. Trata-se de uma poética que não se limita à dimensão estritamente estética do documentário ou noticiário; mas de um campo emergente para a inovação ético-política, pois conduz ao desenvolvimento de retóricas audiovisuais não ficcionais, de caráter francamente emancipatório. Tais tipos de arranjos e de formatos são inovadores por implicarem mudanças qualitativas na capacidade de pessoas comuns em criar campos de reflexividade pública para seus discursos.

A TV digital interativa permite que a perspectiva cidadã emerja na cena pública sem ser tratada de maneira paternalista e simplificadora pelas mídias massivas, e sem fragmentá-la numa nebulosa de espaços da visibilidade pública heterogêneos - forte tendência dos processos de mobilização coletiva empreendidos através dos sites de redes sociais

\footnotetext{
${ }^{20}$ Um excelente exemplo é o documentário comunitário Sons da Serra, realizado pelo programa Rede Jovem de Cidadania, produzido pela Associação Imagem Comunitária em 2006. Nele, dois adolescentes seguem um protocolo de gravação de sons da Favela da Serra e de reprodução desses mesmos sons para moradores da comunidade. Esses, por sua vez, têm gravado seus depoimentos, relatando impressões e lembranças relacionadas a tais sons. Ao final, indicam novos sons que consideram interessantes para a caracterização da comunidade.
} 
controlados por corporações transnacionais. Uma coisa é um cidadão isolado gostar da árvore centenária de seu bairro, fazer um vídeo e publicar num site de videosharing, outra coisa é ele participar de um programa televisivo colaborativo no qual ele irá descobrir que as histórias das árvores sobreviventes à especulação imobiliária de toda a cidade são muito parecidas. A perspectiva da experiência pessoal de desrespeito ao ser sistematicamente abordado de modo hostil pela polícia na saída da sua comunidade muda completamente quando se participa de um documentário interativo no qual as várias experiências semelhantes são percorridas, propiciando a percepção do caráter escravocrata da repressão social, a descoberta de que todos os jovens pobres da América Latina são perseguidos.

\section{Máscaras para quê? Reflexividade, universalidade e outros dilemas éticos da estilística colaborativo-interativa}

O papel da comunicação social de massa é decisivo para enfrentar o desafio da fragmentação da experiência social correlato à pluralização de espaços de visibilidade pública cada vez mais estanques. A enorme variedade de práticas de produção de sentido coletivo (também criadoras de sentidos de coletivo) através das imagens de função referencial traz indagações de ordem ética. O que caracteriza o uso democrático do audiovisual atual? Como criar alternativas democráticas de apelo universalista, capazes de oferecer soluções para os cruéis problemas de dissonância cognitiva e de isolamento normativo das "comunidades sintéticas" geradas por discursos identitários exclusivistas?

A experiência de uso de modos públicos de endereçamento em noticiários e documentários deixou de ser definida pela referência a uma esfera pública universalista hegemônica. Não se pode contar sequer - como queriam teóricos como Kluge ou Enzensberger - com o horizonte de um 
contrapúblico proletário universal. O enfraquecimento do compromisso universalista dos modos de públicos de endereçamento são correlatos à insegurança generalizada no espaço urbano, à intolerância religiosa, à multiplicação das moedas e mercados, à fragmentação dos discursos político-institucionais. Condições cognitivas "cruéis" e "transculturais" supostamente arcaicas, medievais ou primitivas, estão retornando, como "iconoclashes" (Latour, 2002): a destruição das imagens dos outros, consideradas sacrílegas, origina uma produção feérica de imagens da destruição; a obscenidade dos outros é combatida por atos ainda mais obscenos; a produção de evidências imagéticas pelos outros, questionada por imagens de confiabilidade insondável, frequentemente numa produção institucionalizada de falsificações (Dean, 2008).

A participação dos públicos aqui preconizada só tem sentido democrático na perspectiva de uma "convergência crítica", isto é, numa confluência de retóricas e arranjos de produção que seja benéfica ao projeto inconcluso da democratização das sociedades contemporâneas. Isso é bastante distinto dos ardis corporativos de apropriação do trabalho voluntário, dos grafos sociais, dos hábitos de consumo, das preferências de voto e dos juízos estéticos dos "amadores".

A referência crítica para a convergência das retóricas comunicativas com participação de públicos é a de Walter Benjamin. Citando Tretiakov, escritor russo transmutado para jornalista agitprop soviético, o autor de $O$ Autor como Produtor redefine a ação progressista dos intelectuais, correlacionando a ampla participação na produção jornalística com a “fusão" de retóricas mediáticas com a superação do fetichismo da autoria:

“...o processo de fusão (...) não somente ultrapassa as distinções convencionais entre os gêneros, entre ensaístas e ficcionistas, entre investigadores e vulgarizadores, mas questiona a própria distinção entre autor e leitor. Neste processo, a imprensa é a instância decisiva, e por isso é dela que tem que partir qualquer análise do intelectual como produtor." (Benjamin, 1986 [1934]: 125). 
Para seguir a orientação de forjar conceitos "de modo algum apropriáveis pelo fascismo" e que "podem ser utilizados para a formulação de exigências revolucionárias na política artística” (Benjamin, 1994), a pedra de toque para o viés crítico sobre a convergência de mídias, com decisiva participação dos públicos, é priorizar, no design dos arranjos de produção, de affordances propiciadoras da autoreflexão dos participantes profissionais e voluntários - sobre a dimensão política das relações de produção de bens simbólicos.

Como diz Benjamin, "refletir sobre sua posição no processo produtivo" é o compromisso central do intelectual progressista, tanto em termos estilísticos quanto ético-políticos, que o "transforma de fornecedor do aparelho de produção intelectual em engenheiro que vê sua tarefa na adaptação desse aparelho aos fins da revolução proletária”.

Não é por acaso que há uma forte tendência de documentários realizados através de relações de produção politicamente progressistas usarem licenças de uso libres e abertas para os bens simbólicos. Os protocolos do software livre, do código aberto e da "ética hacker" conduzem as relações de produção e de apropriação social dos bens simbólicos à ultrapassagem da oposição entre informação e narrativa (vide Benjamin, "O Narrador”...). Uma notícia e um documentário livre ou de código aberto deixam de ser mercadorias, pois adquirem uma uberdade participativa e antinarcótica. Tal como as narrativas tradicionais, bens simbólicos livres "guardam seu poder germinativo": não só não são destruídas pelo uso ou ficam irrelevantes depois dos atos de apreciação; elas transformam seus enunciatários em coenunciadores, convidando-os a reutilizar esses bens simbólicos comuns na produção de outros discursos, sob a única condição de que os mesmos direitos de apropriação livre sejam comunicados para todas as derivações futuras.

Muito além de um mero mecanismo jurídico, o licenciamento libre e aberto cria possibilidades para experimentação poético-conceitual, porque 
faz das próprias relações de produção de sentido uma matéria de expressão: os usuários tornam-se coautores do material audiovisual quando, acatando as licenças de uso, concretizam no uso compromissos políticos específicos. Por exemplo: uma licença pode proibir a exibição para fins comerciais, salvo se for para sustentar organizações de defesa de direitos; pode liberar o reúso do material, desde que em obras derivadas de orientação política emancipatória; pode facultar o acesso ao material bruto, desde que os teleusuários remetam suas avaliações e obras derivadas para os produtores originais.

A lógica da circulação social de bens simbólicos libres e abertos propicia a criação através da reciclagem da própria proposição de participação coletiva, traduzindo elementos provenientes de proposições de participação anteriores. Reativam, por isso, condições gerativas combinatórias semelhantes àquelas típicas de narrativas tradicionais. Não é só que o cinema contemporâneo reabre as possibilidades dos cinemas das origens (Kluge, Hansen, Almeida): as relações discursivas possibilitadas pelo audiovisual interativo podem emancipar os públicos da ordem audiovisual imposta pela sua transformação em empreendimento capitalista.

\section{Referências Bibliográficas}

AARSETH, E. J. (1994), "Nonlinearity and Literary Theory” in LANDOW, George P. (Ed.), Hyper/text/theory, Baltimore, Londres: John Hopkins University Press, pp. 51-86.

(1997), Cybertext. Perspectives in ergodic literature, Baltimore, Londres: John Hopkins University Press.

ALVARENGA, Clarisse M. C. (2004), Vídeo e experimentação social: um estudo sobre o vídeo comunitário contemporâneo no Brasil. 
Campinas, SP: Dissertação de Mestrado, Universidade Estadual de Campinas: [s.n.].

ARENDT, Hannah (1999), Eichman em Jerusalém; um relato sobre a banalidade do mal. São Paulo: Companhia das Letras [1963]. (1987) “Collective Responsibility,” in BERNHAUER, James (ed.), Amor Mundi. Dordrecht: M. Nijhoff.

BARBOSA FILHO, André (2015), Interatividade: surge uma nova televisão. Disponível em http://www.ebc.com.br/brasil-4d/2015/04 /interatividade-surge-uma-nova-televisao

BARDONE, Emanuele (2010) "Affordances as abductive anchors" in Studies in Computational Intelligence Volume 314, pp. 135-157. (2011), Seeking Chances - From Biased Rationality to Distributed Cognition. Berlim: Springer.

BAUDRY, Jean-Louis (1983) “Cinema: efeitos ideológicos produzidos pelo aparelho de base" in XAVIER, Ismail (Org.), A experiência do cinema, Rio de Janeiro: Graal, pp. 383-410 [1970].

BAUM, Gabriel; SOARES, Luiz Fernando Gomes (2012), Ginga Middleware and Digital TV in Latin America. Disponível em: http://www.telemidia.puc-rio.br/sites/telemidia.puc-rio.br/files/ baum_2012.pdf

BENDOR, Roy; LYONS, Susanna Haas; ROBINSON, John. What's There Not To 'Like'? The Technical Affordances of Sustainability Deliberations on Facebook. JeDEM 4(1): 67-88, 2012

BENJAMIN, Walter (1994), "A obra de arte na era de sua reprodutibilidade técnica" in Magia e técnica, arte e política: ensaios sobre literatura e história da cultura, São Paulo: Brasiliense, pp. 165-196.

BENKLER, Yochai (2000) From Consumers to Users: Shifting the Deeper Structures of Regulation Toward Sustainable Commons and User Disponível em: http://www.yale.edu/lawweb/jbalkin/telecom/ benklerfromconsumerstousers.pdf 
BURCH, Noel (1991), La Lucarne de l'infini: naissance du langage cinematographique. Paris: Nathan.

CARROLL, Noël, Theorizing the moving image (1996), Cambridge, Melbourne: Cambridge University Press. Cap. 15: "From real to reel: entangled in non fiction film", pp. 224-252.

CLARK. Lygia (1997), Barcelona: Fundació Antoni Tàpies.

COLEMAN, Gabriella (2004), "Indymedia's Independence; From Activist Media to Free Software" in Planetwork Journal, July. Disponível em: http://autonomousuniversity.org/sites/default/files/Biella_Cole man-Indymedia's-Independence.pdf (2012), Coding freedom: the ethics and aesthetics of hacking, Princeton (EEUU) e Woodstock (RU): Princeton University Press.

COSTA, Flávia Cesarino (2005), O primeiro cinema: espetáculo, narração, domesticação. Rio de Janeiro: Azougue Editorial.

DANTAS, Marcelo (2009), “Onde os francos não tem vez: como evoluiu e como evoluiu a TV digital no Brasil" in SQUIRRA, S.; FECHINE, Y. (Orgs.), Televisão digital: desafios para comunicação, Porto Alegre: Sulina, pp. 275-300.

DEAN, Jodi (2008), "Communicative Capitalism: Circulation and the Foreclosure of Politics" in BOLER, Megan (ed.), Digital Media and Democracy: tactics in hard times, Cambridge, Londres: The MIT Press, pp. 101-122.

DINIZ, Rafael; NOVAES, Thiago (2015), “A reinvenção da TV Digital no Brasil" in Carta Capital, Intervozes. Disponível em: http://www.cartacapital.com.br/blogs/intervozes/a-reinvencao-da-tvdigital-no-brasil-4423.html

DRYZEK, John S. (2000), "Discursive Democracy vs. Liberal constitucionalism" in SAWARD, Michael (ed.), Democratic Innovation - Deliberation, Representation and Association, Nova Iorque e Londres: Routledge, ECPR. 
GALLOWAY, Alexander R.; THACKER, Eugene (2007), The exploit, Minneapolis, London: University of Minnesota Press.

HANSEN, Miriam (2007), "Reinventando os Nickelodeons: Considerações sobre Kluge e o primeiro cinema" in ALMEIDA, Jane de (Organizadora), Alexander Kluge: o Quinto Ato, São Paulo: Cosac e Naify, pp.43-66.

(1994), "Early cinema, late cinema" in WILLIAMS, Linda (org.), Viewing Positions, Nova Brunswick, Nova Jérsei: Rutgers University Press.

HERZOG, Werner (2005), “Coração Selvagem. Paulo Camargo e Carlos Augusto Brandão" (texto e entrevista) in Jornal Gazeta do Povo, 31 Jan, Curitiba: Caderno G.

KLUGE, Alexander (2007), “Onze histórias do cinema” in ALMEIDA, Jane de (Org.), Alexander Kluge: o Quinto Ato, São Paulo: Cosac e Naify, pp.79-104.

LATOUR, Bruno; WEIBEL, Peter (2002), Iconoclash, beyond the ImageWars in Science, Religion and Art, ZKM and MIT Press.

LEWANDOWSKA, Marysia. "From Enthusiasm to Creative Commons" in BILLING, Johanna; LIND, Maria; NILSSON, Lars (2007), Taking the matter into common hands: on contemporary art and collaborative practices. Londres: Black Dog Publishing, pp. 47-53.

MAGNANI, Lorenzo; BARDONE, Emanuele (2008), Distributed morality: externalizing ethical knowledge in technological artifacts, Foundations of Science,V 13, I 1.

MATUCK, A. (1995), O potencial dialógico da televisão, São Paulo, Annablume.

MOTA, Regina (2009), "Novos formatos para a TV digital no Brasil" in SQUIRRA, S.; FECHINE, Y. (Orgs.), Televisão digital: desafios para comunicação, Porto Alegre: Sulina, pp. 231-246. 
NEVES, Bráulio de Britto. “Algumas Questões Para O DocumentárioInterface”. Doc On-Line: revista digital de cinema documentario, v. 13, p. 148-170, 2012.

(2010a), “Imagens-câmera, máquinas lógicas e retóricas documentárias" in Semeiosis: semiótica e transdisciplinaridade em revista, v. 1, p. 1-18.

(2010b), "Prefiguração de contrapúblicos em Brad - Uma noite mais nas barricadas" in Revista Galáxia - Revista do Programa de PósGraduação em Comunicação e Semiótica da Puc - SP, vol. 10, n. 20, São Paulo-SP, dez.

_ (2000), Educação mediática: novos espaços, outras autorias, Presença Pedagógica, v. 6, pp. 71-79.

NICHOLS, Bill (1994), Blurred boundaries: questions of meaning in contemporary culture, Indianápolis: Indiana University Press.

ODIN, Roger (1984), "Film documentaire, lecture documentarisante" in Cinémas et Réalités (Travaux XLI), Saint-Étienne: Centre Interdisciplinaire d'Étude et de Recherches sur l'Éxpression Contemporaine, Université de Saint-Étienne.

RAMOS, Fernão Pessoa (2008), Mas afinal... o que é mesmo documentário? São Paulo: Senac/SP. (2005), “A Cicatriz da Tomada: documentário, ética e imagemintensa" in RAMOS, Fernão (org.), Teoria contemporânea do cinema, vol. II. São Paulo: SENAC, pp. 159-228.

RENOV, Michael (2004), The subject of documentary, Minneapolis: University of Minnesota Press.

SAMUEL, Alexandra W. (2004), Hacktivism and the future of political participation. Cambridge: Harvard University, (Tese de Doutorado, 2004). Disponível em: http://www.alexandrasamuel.com/ dissertation/pdfs/Samuel-Hacktivism-entire.pdf 
SHAW, Aaron; BENKLER, Yochai (2012), “A tale of two blogospheres: discursive practices on the Left and Right" in American Behavioral Scientist, 56(4) 459-487.

SOARES, Luiz Fernando Gomes (2013), "Interatividade na TV Digital Aberta Brasileira" in Revista Lumina, UFJF, v. 7, n. 2.

SOBCHACK, Vivian Carol (1982), "Toward inhabited space: The semiotic structure of camera movement in the cinema" in Semiotica, n. 41, vol I/4, pp. 317-335. Amsterdã: Mouton Publishers.

(1992), The address of the eye: a phenomenology of film experience, Princeton: Princeton University Press.

SONTAG, Susan (1981), Ensaios sobre fotografia, Rio de Janeiro: Arbor.

SOUKI, Nádia (1998), Hannah Arendt e a Banalidade do Mal, Belo Horizonte: Editora UFMG.

SPOLIN, Viola (2005), Improvisação para o teatro, São Paulo: Perspectiva.

STOLLER, Paul (1992), "Artaud, Rouch, and The Cinema of Cruelty" in Visual Anthropology Review, vol. 8, Issue 2, pp. 50-57, Set.

TOMAS, David (1996), Transcultural spaces and transcultural beings, Boulder: Wesview Press.

(1995), “Art, Psycastenic Assimilation, and the Cybernetic Automaton" in GRAY, Chris Hables; FIGUEROA-SARRIERA, Heidi J.; MENTOR, Steven (eds.), The Cyborg Handbook, Nova Iorque, Abingdon: Routledge, pp. 255-266.

TOZETTO, Claudia (2012), “TV pública quer liderar criação de conteúdo para Ginga - Para evitar que futuro do sistema para TVs dependa de emissoras comerciais, TV Brasil aposta em serviços públicos”, iG São Paulo, Secção Tecnologia. Disponível em: http://tecnologia.ig. com.br/especial/tv-publica-quer-liderar-criacao-de-conteudo-paraginga/n1597727279334.html 
TRYON, Chuck (2011), "Digital distribution, participatory culture, and the transmedia documentary" in Jump Cut, n. 53, verão. Disponível em: http://www.ejumpcut.org/archive/jc53.2011/index.html

VEHLKEN, Sebastian (2013), "Zootechnologies: Swarming as a Cultural Technique" in Theory, Culture \& Society 0(0) 1-22.

ZAMORA, Amanda (ProPublica, Dec. 12, 2012), Crowdsourcing campaign spending: What we learned from free the files. Disponível em: http://www.propublica.org/article/crowdsourcing-campaignspending-what-we-learned-from-free-the-files

\section{Filmografia}

99\% Occupy Wall St. Collaborative Film, (2013) de Aaron Aites, Audrey

Ewell, Nina Krstic e Lucian Read

À bientôt, j'espère (1968), de Chris Marker/Coletivo Dziga Vertov

A Corporação (The Corporation) (2003) de Mark Achbar, Jennifer Abbott

A era da estupidez (Age of stupid) (2009) de Franny Armstrong, Lizzie

Gillett

Amador (2011), de Néstor Frenkel

Amator (1979), de Krzysztof Kiesowsky

Boca de lixo (1993), de Eduardo Coutinho

Classe de lutte (1969), de Chris Marker/Coletivo Dziga Vertov

Crônica de um Verão (Chronique d'un Été) (1961), de Jean Rouch e Edgar

Morin

Essa é a Cara da Democracia (This is what democracy looks like), de Corrugated Films, Indymedia, 2001

Europa em 5 minutos (1986), de Eder Santos

La Commune (2000), de Peter Watkin. 
Documentários com ginga ...

Sons da Serra, (2006), de Rede Jovem de Cidadania (Associação Imagem Comunitária)

Surname Viet Given Name Nam (1989), de Trinh T. Minh-ha

Uma verdade inconveniente (2006), de Davis Guggentheim

Uncovered: The War on Iraq (2004), de Robert Greenwald

Uncovered: the whole truth about the Iraq War (2003), de Robert Greenwald

Verdades e Mentiras (F for Fake) (1973), de Orson Welles 